$$
\text { ノ-ト Note }
$$

(J.Soc.Cosmet.Chem.Jpn.)

$\left(\begin{array}{ll}34(4) \quad 395-400(2000)\end{array}\right)$

\title{
ADF/TRX の産生に及ぼす植物抽出物の影響*
}

\author{
田中弘**, 船坂陽子***, 市橋正光*** \\ 株式会社ナリス化粧品 研究開発部** \\ 神戸大学医学部皮膚科学教室 ${ }^{* * *}$
}

UV-B 照射後, ケラチノサイト培養上清中に存在する, チロシナーゼ活性を増加させる物質を確認す るために, $\mathrm{ADF} / \mathrm{TRX}$ 抗体， $\alpha$-MSH 抗体を使用して検討を行った。その結果，ケラチノサイト培養上 清中に $\mathrm{ADF} / \mathrm{TRX}$ 抗体, および $\mathrm{ADF} / \mathrm{TRX}$ 抗体 $+\alpha-\mathrm{MSH}$ 抗体を添加したメラノサイトのチロシナーゼ 活性は，抗体を加えない場合と比較していずれも有意に抑制した。次に，紫外線により充進されるメラ ニン産生を抑制するという観点から, UV-B 照射時にケラチノサイトから産生される ADF/TRXの産生 を抑制する物質の検索を行った。その結果, $d l-\alpha$ トコフェロールのほか, グアバ葉抽出物, 茶抽出物, ヒマワリ種子エキス等の物質が, UV-B 照射時のケラチノサイトにおいて産生される ADF/TRX を抑制 することが確認できた。

\section{1. 緒言.}

Adult T Cell Leukemia-Derived Factor/チオレド キシン $(\mathrm{ADF} / \mathrm{TRX})$ は, 分子量 $12 \mathrm{kDa}$ の小さな タンパクで, Cys-Gly-Pro-Cys というよく保存さ れた活性部位を持ち, NADPH, チオレドキシン 還元酵素依存性にこの二つのシステインを介した 還元作用を通して，標的タンパク分子のジスル フィド結合を還元する作用を示す酸化還元酵素で ある。ADF/TRXは, TRX 依存性 peroxidase (peroxiredoxin）とともに過酸化水素，ヒドロキシラ ジカルなどを消去するラジカルスカベンジャーと しての活性を示すほか, 細胞外へ放出されサイト カイン様作用を示す等, 多彩な生物活性を有する ことが示されている1。

また，メラノサイトに対する作用に関しては， UV-B 照射によりケラチノサイトから放出された

*2000. 2.28 受理

** テ553-0001 大阪市福島区海老江 1-11-17 : 1-1117, Ebie, Fukushima-ku, Osaka 553-0001, Japan

*** T 650-0017 神戸市中央区楠町7-5-1:7-5-1, Kusunoki-cho, Chuo-ku, Kobe 650-0017, Japan
$\mathrm{ADF} / \mathrm{TRX}$ が,メラノサイトの $\alpha-\mathrm{MSH} の$ 受容体 数を増加させ， $\alpha-\mathrm{MSH}$ と受容体との結合活性を 高めることが報告されている22。そこで，本報告 では UV-B 照射時にケラチノサイトから放出され た $\mathrm{ADF} / \mathrm{TRX}$ の作用をメラノサイトのチロシナー ゼ活性を中心に検討した。さらに，UV-B 照射時 にケラチノサイトから産生される $\mathrm{ADF} / \mathrm{TRX}$ の産 生を抑制する物質の検索を行ったのでその結果に ついて報告する。

\section{2. 実験}

\section{1. 試薬}

ケラチノサイトおよびメラノサイトは Clonetics 社のヒト胎児皮膚ケラチノサイトおよびヒト 胎児皮膚メラノサイトを，ケラチノサイト培地は Gibco 社の keratinocyte-SFM 培地, Ham’s F-10は 大日本製薬, FBS (牛胎児血清) は Gibco 社を使 用した。脳下垂体抽出物は極東製薬工業, insulin, 12- $O$-tetradecanoylphorbol acetate (TPA), Triton X100 は Sigma 社, AG 50 W-X 8 樹脂 (100-200 mesh hydrogen form), protein assay kit $は$ Bio Rad 社, nonylphenoxy polyethoxy ethanol (NP-40), $\alpha$-MSH 
抗体はフナコシ, ADF/TRX 抗体は京都大学ウイ ルス研究生体応答学の淀井淳司教授より分与いた だいたものを使用した。 ${ }^{3} \mathrm{H}$-tyrosine, Immuno star, 抗マウス抗体 (horse radish peroxidase linked whole antibody: from sheep) は Amershamより購入した ものを使用した。その他の試薬は和光純薬工業よ り購入したものを使用した。茶カテキンは常磐植 物化学研究所, グアバ葉エキスは備前化成, ひま わり種子は市販品を購入し， $50 \%$ エタノール水 溶液で抽出したものを使用した。

\section{2. ケラチノサイト培養上清の調製}

r-EGF $5.0 \mathrm{ng} / \mathrm{mL}$, 脳下垂体抽出物 $50 \mu \mathrm{g} / \mathrm{mL}$ を 添加した keratinocyte-SFM 培地で, $8.5 \mathrm{~cm}$ のシャ ーレにケラチノサイトをコンフルエントになるま で培養した。UV-B $20 \mathrm{~mJ} / \mathrm{cm}^{2}$ 照射後, 脳下垂体 抽出物, r-EGF 無添加の keratinocyte-SFM 培地を $7 \mathrm{~mL}$ 添加し, 4 時間, 8 時間, 16 時間, 24 時間, 48 時間培養し, 培養後の培養液を培養上清とし た。 $\mathrm{ADF} / \mathrm{TRX}$ 抗体は $2.0 \mu \mathrm{g} / \mathrm{mL}, \alpha$-MSH 抗体は $50 \mu \mathrm{g} / \mathrm{mL}$ を添加した。

\section{3. メラノサイトの培養}

メラノサイトは, FBS 5\%, insulin $2.5 \mathrm{mg} / 500$ $\mathrm{mL}, \mathrm{IBMX} 1 \times 10^{-4} \mathrm{M}$, 脳下垂体抽出物 $20 \mu \mathrm{g} / \mathrm{mL}$, TPA 50.ng/mL を添加したHam’s F-10 培地で, 6 well プレートにコンフルエントになるまで培養し た後, 除菌ろ過したケラチノサイト培養上清, およびケラチノサイト抽出液をそれぞれ $2 \mathrm{~mL}$ 添 加し 3 日間培養した。

\section{4. メラノサイト抽出物のチロシナーゼ活性} 測定

AG50W-X8 樹脂 (100-200mesh hydrogen form) を $0.1 \mathrm{M}$ クエン酸で洗浄後, カラムに充填した。

遠心分離で集めたメラノサイト細胞に $1 \mathrm{mM}$ phenyl-methyl-sulfonyl-fluoride, $10 \mu \mathrm{g} / \mathrm{mL}$ leupeptine, $10 \mu \mathrm{g} / \mathrm{mL}$ Aprotin, $0.5 \%$ Triton X-100, 0.1 M リン酸水素二ナトリウムで調製した enzyme lysis buffer $50 \mu \mathrm{L}$ を加え, 細胞を溶解した。溶解後, 遠心分離した上清の $1 \mu \mathrm{L}$ を取り, タンパク量を 測定した。タンパク量が $10 \mu \mathrm{g}$ となる細胞溶解液 と, enzyme lysis buffer を合わせて $90 \mu \mathrm{L}$ に調製 した。次に, ${ }^{3} \mathrm{H}$-tyrosine $30 \mu \mathrm{L}(30 \mu \mathrm{ci})$ と L-DOPA
$0.5 \mathrm{mg} / \mathrm{mL}(0.1 \mathrm{M}$ リン酸水素二ナトリウム) 溶 液 $570 \mu \mathrm{L}$ を加え, ${ }^{3} \mathrm{H}$-tyrosine 溶液とした。90 $\mu \mathrm{L}$ に調製した細胞溶解液に, ${ }^{3} \mathrm{H}$-tyrosine 溶液を 10

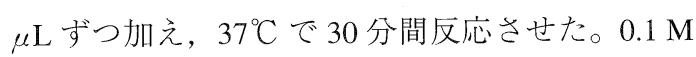
クエン酸溶液に $10 \mathrm{w} / \mathrm{v} \%$ にるように調製した 活性炭溶液 $1 \mathrm{~mL}$ を各チューブに添加して反応を 止め, $15000 \mathrm{rpm}, 5$ 分間遠沈した。液シン溶液 4 $\mathrm{mL}$ を入れたバイアルビンに, $\mathrm{AG} 50 \mathrm{~W}-\mathrm{X} 8$ 樹脂 (100-200 mesh hydrogen form) を充填したカラム を立て，遠沈した上清を添加した。その後，500 $\mu \mathrm{L}$ の $0.1 \mathrm{M}$ クエン酸溶液を添加し, シンチレー ションカウンターで測定した。

データの有意差の検定は対応のない $t$ 検定を行 い，危険率 $5 \%$ 以下を有意水準とした。

\section{5. ケラチノサイトによる ADF/TRX 産生誘} 導試験

6 well プレートに培養したケラチノサイトにサ ンプルを添加し，30 分間インキュベートした。

培地を除去し, PBS (一)を $0.5 \mathrm{~mL}$ 添加し, UV$\mathrm{B}$ を $20 \mathrm{~mJ} / \mathrm{cm}^{2}$ 照射した。その後, PBS (一) を 除去し, ケラチノサイト用培地 $2 \mathrm{~mL}$ を添加し, 3 時間インキュベートした。6 well プレートの細 胞をエッペンチューブに集め, $10 \%$ nonylphenoxy polyethoxy ethanol(NP-40)を $2.5 \mathrm{~mL}, 100 \mathrm{mM}$ Tris塩酸（pH 7.5）を $5.0 \mathrm{~mL}, 3 \mathrm{M}$ 塩化ナトリウムを $2.5 \mathrm{~mL}, 200 \mathrm{mM}$ phenyl-methyl-sulfonyl-fluoride in dimethyl formamide $250 \mu \mathrm{L} \quad(17.4 \mathrm{mg} / 500 \mu \mathrm{L}$ DMFA), $0.111 \mathrm{IU} / \mathrm{ml}$ Aprotinin を $185 \mu \mathrm{L}, 10 \%$ アジ化ナトリウムを $100 \mu \mathrm{L}$ 加え, 蒸留水で $50 \mathrm{~mL}$ とした lysis buffer $30 \mu \mathrm{L}$ を添加し, よく擋拌溶解 した。細胞溶解液を $15000 \mathrm{rpm}, 5$ 分間遠心分離し, 上清を新しいエッペンチューブに取り, ADF/TRX 確認用の試料とした。次に, ウエスタンブロッティ ングにより $\mathrm{ADF} / \mathrm{TRX}$ タンパクの確認を行った。

$\mathrm{ADF} / \mathrm{TRX}$ 抗体 $1 \mu \mathrm{L}$ を $7 \mathrm{~mL}$ の $0.05 \%$ Tween 20 PBS (一) に希釈し, 室温で 1 時間処理した。さ らに, 二次抗体 (抗マウス抗体) $10 \mu \mathrm{L} 6 \mathrm{~mL}$ の $0.05 \%$ Tween 20-PBS (-) に希釈し, 室温で 1 時間処理した。最後に Immuno starで ADF/TRX タンパクを発色させ, バンドを確認した。 


\section{6. 植物エキスの抗酸化性試験}

$0.1 \mathrm{M}$ リン酸緩衝液（pH 7.0） $0.8 \mathrm{~mL}, 20 \%$ 工

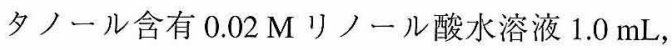
および各植物エキスを溶解した水溶液 $0.2 \mathrm{~mL}$ 加え， $37^{\circ} \mathrm{C}$ に放置した。 72 時間後，試料溶液 0.05 $\mathrm{mL}$ を取り出し，75 v/v\%エ夕ノール水溶液 2.35 $\mathrm{mL}, 30 \mathrm{w} / \mathrm{w} \%$ チオシアン酸アンモニウム水溶液 $0.05 \mathrm{~mL}, 0.02 \mathrm{M}$ 塩化第一鉄水溶液（10\% 濃塩酸 含有） $0.05 \mathrm{~mL}$ を加六， $500 \mathrm{~nm}$ の吸光度を測定し た。

\section{3. 結果}

\section{1. メラノサイトのチロシナーゼ活性}

UV-B $20 \mathrm{~mJ} / \mathrm{cm}^{2}$ 照射後のケラチノサイト培養 上清で培養したメラノサイトのチロシナーゼ活性 は，UV-B 照射後 4 時間培養したケラチノサイト 培養上清を添加したメラノサイトで有意に上昇し， 24, 48 時間後のケラチノサイト培養上清でも高

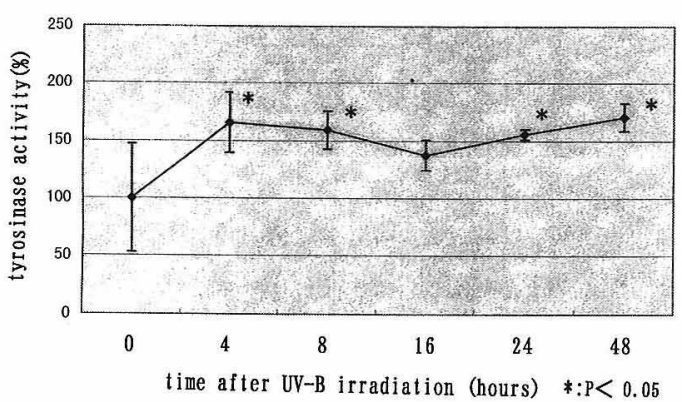

Fig. -1 The effect of the conditioned medium of keratinocytes after UV-B irradiation on the tyrosinase activities of melanocytes.
い活性を示した（Fig. -1）。

この結果より, 以後の抗体を添加する実験にお いては, UV-B 照射後 24 時間培養したケラチ， サイト培養上清を用いた。これらの対照実験とし て，UV-B 非照射のケラチノサイト培養上清を添 加したメラノサイトのチロシナーゼ活性は，いず れの場合も有意差は認められなかった。

次に, UV-B $20 \mathrm{~mJ} / \mathrm{cm}^{2}$ 照射後, 24 時間培養し たケラチノサイト培養上清中に存在するチロシナ 一ゼ活性を増加させる物質を確認するために，各 種抗体を添加した。抗体は ADF/TRX抗体， $\alpha$ $\mathrm{MSH}$ 抗体を使用した。年の結果, $\mathrm{ADF} / \mathrm{TRX}$ 抗 体 $2.0 \mu \mathrm{g} / \mathrm{mL}$ お よび, $\mathrm{ADF} / \mathrm{TRX}$ 抗体 $2.0 \mu \mathrm{g} / \mathrm{mL}$ $+\alpha$-MSH 抗体 $50 \mu \mathrm{g} / \mathrm{mL}$ を添加したメラノサイ トのチロシナーゼ活性は，抗体を加えない場合と 比較して，それぞれ $62.8 \%$ ，および $55.8 \%$ と有 意に抑制した。また， $\alpha$-MSH 抗体を $50 \mu \mathrm{g} / \mathrm{mL}$ 添加した場合は，75.4\% に抑制したが，有意差は 認められなかった（Fig.-2)。また，これらの対 照実験として行った，UV-B 非照射のケラチノサ イト培養上清に Fig. -2 と同じ抗体を添加したメ ラノサイトのチロシナーゼ活性測定では，いずれ の場合においても有意差は認められなかった。

\section{2. ケラチノサイトが産生する ADF/TRXの} 確認

UV-B 照射時にケラチノサイトから産生される $\mathrm{ADF} / \mathrm{TRX}$ が，メラノサイトに対してチロシナー ゼ活性を有意に上昇させることが判明した。その ため，紫外線照射時のメラニン産生を抑制する目 的で，さまざまな物質の存在下における UV-B 照

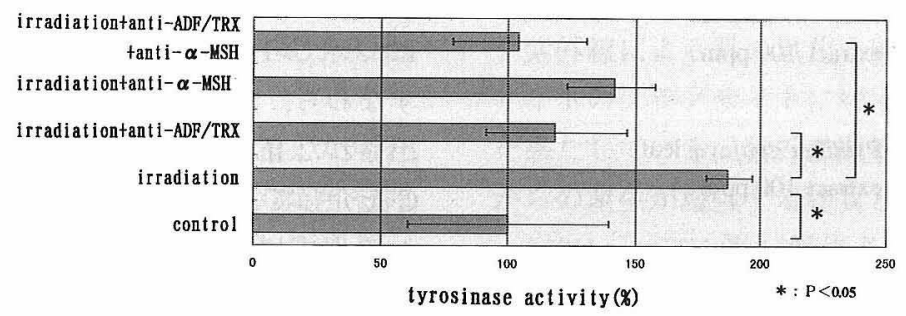

Fig. - 2 The stimulatory effect of the conditioned medium from UV-B exposed keratinocytes on the tyrosinase activities of melanocytes and its suppression by $\alpha$-MSH and ADF/TRX antibodies. 
射時のケラチノサイトから産生される $\mathrm{ADF} / \mathrm{TRX}$ タンパクをウエスタンブロッティングにより確認 した (Fig. - -3)。

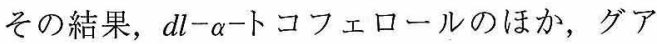
バ葉抽出物, 茶抽出物, ヒマワリ種子エキス等の 物質が，UV-B 照射時のケラチノサイトにおいて 産生される ADF/TRX を抑制することが確認でき た (Table-1)。

\section{3. 植物エキスの抗酸化性}

次に TDF/TRXの産生を抑制した植物抽出物の 抗酸化性の測定を行った。測定は,リノール酸の 酸化をロダン鉄法により測定した（Table-2）。結 果は Table-2に, 本実験条件においてリノール酸 の酸化を $50 \%$ 抑制する抽出物の濃度で示した。 ケラチノサイトの ADF/TRXの産生を抑制した植 物抽出物は, いずれも高い抗酸化性を示した。

\section{4. 考察}

皮膚に紫外線が照射されると，皮膚の細胞から

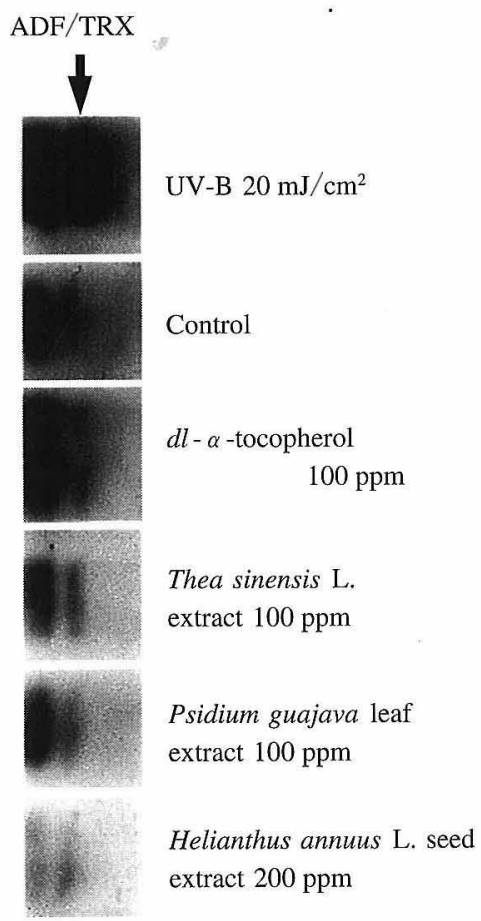

Fig. -3 The detection of ADF/TRX protein derived from keratinocytes after UV-B irradiation.
Table-1 The list of suppressive ingredients of $\mathrm{ADF} / \mathrm{TRX}$ production.

$d l-\alpha$-Tocopherol
Helianthus annuus L. seed extract
Thea sinensis L. extract
Psidium guajava L. leaf extract

Table-2 The antioxidative activity of plant extracts.

\begin{tabular}{lc}
\hline & IC $_{50}(\mu \mathrm{g} / \mathrm{mL})$ \\
\hline Helianthus annuus L. seed extract & 5.0 \\
Thea sinensis L. extract & 23 \\
Psidium guajava L. leaf extract & 15 \\
$d l-\alpha$-Tocopherol & 0.31 \\
\hline
\end{tabular}

Table- 3 The cytokines derived from keratinocytes.

\begin{tabular}{ll}
\hline IL-1 & GM-CSF \\
IL-3 & G-CSF \\
IL-6 & M-CSF \\
IL-8 & TGF- $\alpha$ \\
IL-10 & TGF- $\beta$ \\
TNF- $\alpha$ & b-FGF \\
\hline
\end{tabular}

はさまざな物質が産生される。ケラチノサイトか ら放出されるサイトカインには, Table-3に示す 物質が報告されており ${ }^{3)}$, 紫外線照射時には, IL1，IL-3，GM-CSF 等は産生が増幅される4)。

また，サイトカインだけではなく， $\alpha-\mathrm{MSH}$, $\mathrm{ACTH}$ 等のホルモン類 ${ }^{5)}$ ，および $\mathrm{PGE}_{2}, \mathrm{LTD}_{4}$ 等の エイコサノイドや, 各種の活性酸素種の生成が起 こり，皮䖉の炎症や黒化に関与していることが知 られている(6) 8)。紫外線照射時に抢ける, ケラチ ノサイトを介したメラニン産生のメカニズムにつ いては，IL-1によって生成されるエンドセリン についての報告が芋川らによりなされている9。 すなわち, 紫外線照射時にケラチノサイトから放 出されたIL-1 がエンドセリンの産生を促し, PKCを介してメラニン産生を充進する。エンドセリ ンの生成には IL-1の存在が必要なため, この系 ではケラチノサイトにUV-B を照射後，4日間培 養した培養上清を用いて実験を行っている。しか し, 本実験においては, 紫外線照射直後より生じ る皮膚の酸化傷害に関係する $\mathrm{ADF} / \mathrm{TRX}$ の作用を 
検討するために，UV-B 照射後から 48 時間まで の培養上清を中心に検討を行った。UV-B 照射時 にケラチノサイトより産生される物質で, メラノ サイトのチロシナーゼ活性を立進させる物質とし ては, b-FGF, $\mathrm{PGE}_{2}, \mathrm{LTD}_{4}, \alpha-\mathrm{MSH}, \mathrm{ACTH}$ が 知られている ${ }^{10)}$ 。われわれは $\alpha-\mathrm{MSH}, \mathrm{ACTH}$ 関して, UV-B $25 \mathrm{~mJ} / \mathrm{cm}^{2}$ 照射後 24 時間培養した ケラチノサイトの細胞内で, $\alpha$-MSH の産生が 240 $\%$ ，培養上清では $279 \%$ 増加すること，さらに ACTH に関しては，細胞内で $254 \% ，$ 培養上清で は $259 \%$ 増加することを報告した ${ }^{11) 。 ま た, ~} \mathrm{ADF} /$ TRXは $5 \mu \mathrm{g} / \mathrm{mL}$ 存在下において, $\alpha$-MSHとメ ラノサイトの $\alpha$-MSH 受容体の結合活性を $284 \%$ に増加させるとともに, IL-1 についても $100 \mathrm{pg} /$ $\mathrm{mL}$ 存在下で, 結合活性を $183 \%$ に増加させるこ とを報告した2)。

Fig. -1 より，培養ケラチノサイトにUV-B 20 $\mathrm{mJ} / \mathrm{cm}^{2}$ 照射後, 4 時間培養した培養上清は, メ ラノサイトのチロシナーゼ活性を約 1.6 倍に上昇 させ，さらにUV-B 照射後 48 時間培養した培養 上清まで同じ傾向を示した。これは UV-B 照射後, ケラチノサイトから産生された $\mathrm{ADF} / \mathrm{TRX} や ，$ 同 時に産生された $\alpha-\mathrm{MSH}, \mathrm{ACTH} の$ 作用により, チロシナーゼ活性の上昇を示したものと考えられ る。

そこで, UV-B 照射後のケラチノサイト培養上 清中のチロシナーゼ活性促進物質確認のため， $\alpha$ $\mathrm{MSH}$ 抗体, $\mathrm{ADF} / \mathrm{TRX}$ 抗体を用いてその作用を 確認した。その結果, ADF/TRX抗体添加系, および, $\mathrm{ADF} / \mathrm{TRX}$ 抗体 $+\alpha-\mathrm{MSH}$ 抗体添加系に おいて，いずれもチロシナーゼ活性を低下させた。 これにより本実験系で認められたチロシナーゼ活 性の上昇は, $\mathrm{ADF} / \mathrm{TRX}$ および $\alpha-\mathrm{MSH}$ をした ものであることが明らかとなった。

$\mathrm{ADF} / \mathrm{TRX}$ の観点から美白化粧品を考えた場合, UV-B 照射時に産生される $\mathrm{ADF} / \mathrm{TRX}$ の産生を抑 制することが一つの方法として考えられる。 $\mathrm{ADF} / \mathrm{TRX}$ は，活性酸素などの酸化ストレスによ り産生が誘導される物質で, 生体の酸化ストレス

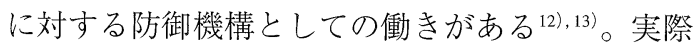
に, Table-1 に示したようにケラチノサイト培養

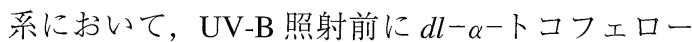
ルで処理したケラチノサイトにUV-B を照射し， $\mathrm{ADF} / \mathrm{TRX}$ の産生を調べると，その産生は著しく 抑制された。また, グアバ葉抽出物, 茶抽出物, ヒマワリ種子エキス等の植物抽出物の添加によっ ても ADF/TRXの産生が抑制された。トコフェロ ールは, 生体内で酸化還元反応に関与する物質で あり，また，グアバ葉抽出物，茶抽出物，ヒマワ リ種子エキスは Table-2に示したようにいずれも 抗酸化活性が強い物質である。これは, UV-B 照 射により生じる活性酸素ストレスが, 細胞内に供 給された抗酸化物質により消去され, $\mathrm{ADF} / \mathrm{TRX}$ の産生の誘発が抑制されたものと考えられる ${ }^{14)}$ 。

このため, 紫外線により忘進されるチロシナー ゼ活性の抑制という観点から, 生体の抗酸化活性 を高く保ち，かつ紫外線等の酸化ストレスにより 誘発される $\mathrm{ADF} / \mathrm{TRX}$ の産生を抑制することは有 効な方法であると考える。

従来, 美白化粧品ではメラノサイトのメラニン 産生を直接的に抑制する素材の開発が進められて きた。しかし, 研究が進むにつれメラノサイトで のメラニン産生は, その周囲に位置するケラチノ サイトをはじめとしたさまざまな細胞の作用を受 けていることが明らかになってきた。そのため, これからの効果的な美白化粧品としては, 直接的 なメラノサイトへの作用だけでなく，ケラチノサ イトや, 線維芽細胞から産生される各種の情報伝 達物質の作用を調整することにより，間接的にメ ラニン産生を抑制する物質の開発が必要になると 考える。

\section{5. 結論}

紫外線による肌の黒化を考える場合，ケラチノ サイトのメラノサイトに対する作用が大きな役割 を果たしている。紫外線照射時にケラチノサイト からの産生が増強する物質としては, ET-1, b-FGF, $\alpha-\mathrm{MSH}, \mathrm{ACTH}$ 等が報告されてきた。そのなか で, $\mathrm{ADF} / \mathrm{TRX} に$ 着目し検討した結果, $\mathrm{ADF} / \mathrm{TRX}$ 抗体， $\alpha$-MSH 抗体を用いた抑制実験において, UV-B 照射時にケラチノサイトから産生される $\mathrm{ADF} / \mathrm{TRX}$ ，および $\alpha-\mathrm{MSH}$ が，メラノサイトの 
チロシナーゼ活性を立進させることが示された。 さらに, UV-B 照射時にケラチノサイトから産生 される $\mathrm{ADF} / \mathrm{TRX}$ の産生は, グアバ葉抽出物, 茶 抽出物，ヒマワリ種子エキス等の植物抽出物によ り抑制された。このため, UV-B 照射時にケラチ ノサイトから産生される ADF/TRX をグアバ葉抽 出物, 茶抽出物, ヒマワリ種子エキス等の植物抽 出物により抑制することによって，紫外線により 充進されるメラノサイトのチロシナーゼ活性を抑 制することが可能であると考えられる。

\section{引用文献}

1）田中 享, 別冊・医学のあゆみ, 生体応答学の 新展開, 医歯薬出版 (1999) p.218-220

2) Y. Funasaka, M. Ichihashi, Pigm. Cell Res., 10, 6873 (1997)

3）玉置邦彦，皮膚臨床，35, 1201-1206 (1993)

4）西岡 清, 大田幸則, 皮膚病診療，12，397-400 (1990)
5) E. Schauer, F. Trautinger, A. Kock, A. Schwarz, R. Bhardwaj, M. Simon, J. C. Ansel, T. Schwarz, T. A. Luger, J. Clin. Invest., 93, 2258-2262 (1994)

6）佐藤義昭編，光線過敏症，金原出版 (1991) p.54

7）富田靖, Fragrance J., 6, 20-23 (1990)

8) K. Maeda, Y. Tomita, M. Fukuda, H. Tagami, J. Soc.Cosmet. Chem. Jpn., 26, 171-176 (1992)

9) G. Imokawa, Y. Yada, M. Miyagishi, J. Biol. Chem., 267, 24675-24680 (1992)

10）船坂陽子，皮膚臨床，35，1371-1379 (1993)

11) A. K. Chakraborty, Y. Funasaka, A. Slominski, G. Ermak, J. Hwang, J. M. Pawelek, M. Ichihashi, Biochim. Biophys. Acta, 1313, 130-138 (1996)

12）淀井淳司, Mol. Med, 30, 454-462 (1993)

13）西山 晃, 笹田哲朗, 淀井淳司, 組織培養, 22 , 151-154 (1996)

14）増谷弘, 中村 肇, 淀井淳司, 別冊·医学の あゆみ, 生体応答学の新展開, 医歯薬出版 (1999) p. 174

\title{
The Effect of Plant Extracts on Production of Adult T Cell Leukemia-Derived Factor/Tioredoxin (ADF/TRX)*
}

\author{
Hiroshi Tanaka**, Yoko Funasaka***, Masamitsu Ichihashi*** \\ Research \& Development Department, Naris Cosmetics Co., Ltd. ${ }^{* *}$ \\ Department of Dermatology, Kobe University School of Medicine * $^{* *}$
}

\begin{abstract}
With the aim to recognize the materials which increase the tyrosinase activity of melanocytes in the conditioned medium of keratinocytes after UV-B irradiation, we studied the stimulatory effects of conditioned media using ADF/TRX and $\alpha$-MSH (melanocyte stimulating hormone) antibodies. As a result of the studies, all tyrosinase activities of melanocyte in the conditioned media with ADF/TRX and/or $\alpha$-MSH antibodies were suppressed efficiently as compared to the medium without the antibodies. As melanin amount is up-regulated by UV-B irradiation that causes skin pigmentation, we searched for a way to suppress the amount of ADF/ TRX produced during UV-B irradiation. We found the ingredients that effectively suppress the amount of ADF/TRX, as follows : $d l$ - $\alpha$-tocopherol, Psidium guajava leaf extract, Thea sinensis L. extract and Helianthus annuus L. seed extract.
\end{abstract}

Key words : Adult T Cell Leukemia-Derived Factor/Tioredoxin (ADF/TRX), tyrosinase activity, keratinocyte, melanocyte, skin pigmentation, UV-B irradiation, conditioned medium, Western blotting, $d l-\alpha$-tocopherol, Psidium guajava leaf extract, Thea sinensis L. extract, Helianthus annuus L. seed extract 